\title{
APAKAH KESULITAN REGULASI EMOSI BERPENGARUH TERHADAP DANGEROUS DRIVING BEHAVIOR SOPIR BUS ANTAR-KOTA?
}

\section{DOES THE DIFFICULTY OF EMOTION REGULATIONS AFFECT ON DANGEROUS DRIVING BEHAVIOR OF INTER-CITY BUS DRIVER?}

\author{
Rina Desika Priatini' ${ }^{1}$, Sugiyarta Stanislaus ${ }^{2}$, Binta Mu'tiya Rizki ${ }^{3}$ \\ ${ }^{123}$ Universitas Negeri Semarang \\ ${ }^{1}$ rinadesika13@gmail.com
}

\begin{abstract}
Abstrak
Dangerous driving behavior (perilaku mengemudi yang berbahaya) dilakukan oleh banyak sopir bus di Temanggung. Para sopir mengemudi melebihi batas kecepatan maksimum, melanggar peraturan lalu lintas, dan tidak sesuai standar keselamatan yang disebut sebagai perilaku mengemudi yang berbahaya. Perilaku mengemudi yang berbahaya (dangerous driving behavior) salah satunya dipengaruhi oleh faktor emosi. Tujuan penelitian ini yaitu untuk mengetahui pengaruh kesulitan meregulasi emosi terhadap Dangerous Driving Behavior sopir bus antar-kota jurusan Magelang-Sukorejo dan Magelang-Wonosobo y ang melalui jalur Temanggung. Subjek dalam penelitian ini adalah semua sopir bus sedang antar-kota jurusan MagelangSukorejo dan Magelang-Wonosobo yang melalui jalur Temanggung berjumlah 128 orang. Teknik sampling yang digunakan adalah total sampling. Jadi sampelnya berjumlah 128 orang. Pendekatan penelitian yang digunakan adalah penelitian kuantitatif dan desain penelitiannya adalah penelitian korelasi. Data penelitian diambil dengan Dula Dangerous Driving Index (DDDI) yang mempunyai koefisien reliabilitas 0,959 dan Difficulties Emotion Regulation Scale (DERS) yang mempunyai koefisien reliabilitas sebesar 0,963. Hasil analisis data melalui uji korelasi product moment diperoleh nilai koefisien (r) sebesar 0.881 dengan $\mathrm{p}$ sebe sar 0.000 , maka dapat disimpulakan bahwa hubungan antara kesulitan meregulasi emosi dan dangerous driving behavior merupakan hubungan yang positif. Dimanai ketika ada kenaikan pada kesulitan meregulasi emosi, maka dangerous driving behavior juga mengalami kenaikan. Hasil analisis data melalui uji $F$ Test diperoleh $\mathrm{F}$ hitung sebesar 438,989 dengan taraf signifikansi 0,00 ( $\mathrm{p}<0,05)$, maka dapat disimpulkan bahwa kesulitan meregulasi emosi berpengaruh terhadap Dangerous Driving Behavior sopir bus antar-kota jurusan MagelangSukorejo dan Magelang-Wonosobo yang melalui jalur Temanggung. Dimana ketika kesulitan meregulasi emosi tinggi, maka dangerous driving behavior juga tinggi. Hasil perhitungan $R S$ Suare menunjukkan angka 0,777 yang bermakna bahwa regulasi emosi memberikan sumbangan pengaruh sebesar terhadap $77,7 \%$ terhadap dangerous driving behavior sopir bus antar-kota jurusan Magelang- Magelang-Sukorejo dan Magelang-Wonosobo yang melalui jalur Temanggung. Sisanya 23,3\% dipengaruhi oleh faktor-faktor lain yang tidak terungkap dalam penelitian ini, yakni usia, jenis kelamin, etnis, pengalaman mengemudi, faktor personal selain emosi, faktor sosial, dan faktor lingkungan. Kata kunci: dangerous driving behavior, kesulitan regulasi emosi
\end{abstract}

Kata Kunci: dangerous driving behavior; kesulitan regulasi emosi

\begin{abstract}
Driving behavior that exceeds the maximum speed limits, trespassing the traffic rules and drive unsafely are define the dangerous driving behavior seen in the behavior of bus driver in Temanggung. Once of the factor that affecting dangerous driving behavior is emotion. The purpose of this study is to find out the influence of the difficulties of emotional regulation against bus driver's dangerous driving behavior of the MagelangWonosobo and Magelang-Sukorejo region that passing Temanggung. The subject in this study is the 128 bus drivers between Magelang-Wonosobo and Magelang-Sukorejo that passing Temanggung. This study classified as quantitative and correlational research design. This study using Dula Dangerous Driving Index (DDDI) which has coefficient of reliability 0.959 and Difficulties of Emotion Regulation Scale (DERS) that have reliability coefficient of 0.963 . The data was analyzed with the help of data processing software. The result of the data analysis through $F$ Test calculate 438,989 significance level Of $0.00(p<0.05)$ it mean that the emotional regulation evidently had influence on bus driver's dangerous driving behavior of the Magelang-Wonosobo and Magelang-Sukorejo region that passing Temanggung. Which if difficulties of the emotional regulation is high, so the dangerous driving behavioralso high. The result of calculation of $R$
\end{abstract}


Square shows the number of 0.777 defined that bus driver's emotional regulation contributing to the dangerous driving behavior of the Magelang-Wonosobo and Magelang-Sukorejo region that passing Temanggung. The rest of $23.3 \%$ is affected by other factors that are not revealed in this research.

Keywords: difficulties of emotion regulation, dangerous driving behavior

\section{PENDAHULUAN}

Angka kecelakaan lalu lintas di Indonesia masih tergolong tinggi. Sejak tahun 2014 sampai tahun 2016 terjadi peningkatan jumlah kecelakaan lalu lintas secara nasional. Tahun 2014 tercat at sebanyak 95.906 kasus, kemudian tahun 2015 sebanyak 98.970 kasus dan pada tahun 2016 meningkat menjadi 105.374 kasus (Rostianti \& Hafil, 2017). Jadi pada tahun 2015 terjadi peningkatan sebanyak 3,2\% dari tahun sebelumnya dan pada tahun 2016 terjdi peningkat an $6,47 \%$ dari tahun sebelumnya. Ada banyak faktor yang mempengaruhi terjadinya kecelakaan lalu lintas. Salah satunya adalah faktor kesalahan manusia (human error). Pendapat ini didukung oleh Marsaid, Hidayat dan Ahsan (2013) yang menyatakan bahwa faktor manusia memegang peranan penting dalam terjadinya kecelakaan lalu lintas.

Salah satu faktor manusia yang mempengaruhi terjadinya kecelakaan lalu lintas adalah perilaku mengemudi yang berbahaya. Perilaku mengemudi yang berbahaya ditunjukkan oleh sopir bus. Peristiwa kecelakaan akibat ulah sopir bus yang mengemudi tidak aman terjadi di Riau (Tanjung, 2016). Bus menabrak truk fuso dan menyebabkan tiga penumpang bus dan sopir truk meninggal dunia. Kejadian ini terjadi akibat 3 unit bus Intra dari Medan tujuan Pekanbaru saling kejar-kejaran.

Peningkatan angka kecelakaan juga terjadi di Temanggung. Tingginya angka kecelakaan lalu lintas di Temanggung didukung adanya perilaku pengemudi yang berbahaya oleh sopir bus. Hari Senin tanggal 21 Januari 2013 terjadi kecelakaan lalu lintas di Dusun Krikil, Kelurahan Walitelon Selatan, Kabupaten Temanggung (Hazliansyah, 2013). Bus Citra BSM jurusan Sukorejo (Kendal) Magelang yang diduga kebut-kebutan dengan bus lain menabrak tiga sepeda motor.

Peneliti melakukan observasi dengan menjadi penumpang bus jurusan Wonosobo-Magelang. Observasi dilakukan pada tanggal 27 November 2016 pukul 17.00 WIB. Peneliti menaiki bus dari daerah Kedu menuju terminal Secang. Perjalanan ditempuh selama 25 menit. Ketika sampai di jalur arah kota jalan lumayan sempit (lebar jalan 6 meter) dan terjadi kemacetan. Sopir melajukan bus di badan jalan sebelah kanan berusaha mendahului mobil yang ada di depan. Dari arah berlawanan ada satu mobil dan tiga sepeda motor yang melaju. Sopir tetap tidak mengalah dan melajukan bus dengan cepat. Akibatnya mobil dan sepeda motor harus mengerem mendadak dan menghindar supaya tidak terjadi tabrakan. Ketika sampai di kota sopir melanggar lampu lalu lintas dan mengendarai bus dengan kecepatan melebihi batas maksimum kecepatan. Batas maksimum kecepatan yang tertera di rambu-rambu lalu lintas adalah $40 \mathrm{~km} / \mathrm{jam}$, tetapi sopir mengendarai bu s mencapai kecepatan $70 \mathrm{~km} / \mathrm{jam}$. Selain itu, sopir menurunkan penumpang meskipun bus masih berjalan pelan. Sopir mengemudikan bus tidak sesuai standar keselamatan di mana sopir tidak 
memakai sabuk keselamatan, melebihi batas maksimum kecepatan dan melanggar aturan lalu lintas. Perilaku mengemudi seperti ini sangat membahayakan keselamatan, baik keselamatan dirinya, penumpang, maupun pengguna jalan lain.

YS (seorang sopir bus berusia 50 tahun di Temanggung), mengakui bahwa sopir yang kebut kebutan dan membahayakan memang ada. Berdasarkan hasil wawancara dengan YS pada tanggal 30 Mei 2016 didapatkan kesimpulan bahwa kebut-kebutan antar bus satu dengan bus yang lainn ya terjadi karena sopir yang tidak sportif. Bus pintu dua jurusan Magelang-Wonosobo dan MagelangSukorejo memiliki jam jalan yang sudah diatur untuk masing-masing bus. Jarak antara bus yang satu dengan bus setelahnya antara 3-5 km atau 5-7 menit. Menurut YS kebut-kebutan antar bus terjadi karena sopir bus yang di depan melanggar jarak dengan bus di belakangnya. Akibatnya sopir bus yang di belakang tidak terima dan mereka saling kebut-kebutan. Saat bus kebut-kebutan mereka melanggar batas kecepatan maksimal, terkadang sopir juga melanggar rambu lalu lintas dan garis marka.

HA (rekan YS yang berusia 46 tahun) juga membenarkan perilaku sopir bus yang sering kebut-kebutan dan membahayakan. Menurut HA, sopir bus yang melakukan hal tersebut karena tuntutan setoran. Setoran yang diminta oleh perusahaan bus (pemilik bus) biasanya 300-500 ribu rupiah. Sopir kebut-kebutan selain untuk mengejar waktu juga untuk mengejar pen u mpang. Sopir menyerobot wilayah bus lainnya dan terjadi cekcok (pertengkaran verbal lewat telepon) lalu kebut kebutan. Ketika masih muda HA mengaku memiliki emosi lebih labil dan sering emosi sehingga sering kebut-kebutan. Namun, di usia yang sekarang mengaku lebih tenang ketika mengemudi, dan merasa bahwa emosinya sudah stabil.

Hari Selasa tanggal 06 Desember 2016, peneliti melakukan wawancara dengan BG (usia 45 tahun) sopir bus salah satu perusahaan otobus di Temanggung. BG sudah menjadi sopir sejak 20 tahun lalu. Dulu ia pernah menjadi sopir bus ukuran sedang selama 2 tahun. Ketika terjadi krisis moneter perusahaan bus menjual semua bus yang dimiliki. Sehingga sopir di perusahaan tersebut kehilangan perkerjaan. BG kemudian pindah ke perusahaan lain dan menjadi pengemudi bus ukuran kecil. Dulu ketika masih muda BG mengaku mudah marah ketika bus yang melaju di depan berjalan pelan dan berebut mencari penumpang. Ketika emosi sering kebut-kebutan bahkan sampai berkelahi dengan sopir bus lain. Namun usia yang semakin bertambah, ketika sopir emosi hanya sebatas pertengkaran verbal tetapi masih dengan kebut-kebutan. Ketika mengemudikan bus dengan kecepatan yang cepat dan melanggar marka, BG tidak memikirkan penumpang yang ketakutan, sopir hanya memikirkan bus sampai terminal tepat waktu dan mendapatkan penumpang yang banyak. Menurut BG, kebut-kebutan bus tidak hanya terjadi pada bus sedang saja tetapi pada bus kecil juga.

Berdasarkan hasil observasi dan wawancara, diketahui bahwa sopir bus yang mengemudi secara berbahaya karena beberapa faktor, yaitu tidak disiplinnya sopir bus mematuhi jam jalan, sopir yang melanggar wilayah bus lain, tuntutan setoran, dan keinginan mencari penumpang 
sebanyak-banyaknya. Faktor-faktor ini menyebabkan mereka emosi ketika mengemudi. Sehingga mereka berselisih dengan bus lainnya dan terjadilah kebut-kebutan antar bus. Bus yang kebutkebutan ini sangat membahayakan keselamatan dan keamanan penumpang. Selain itu, juga membahayakan keselamatan pengguna jalan lainnya. Seharusnya seorang sopir dapat mengatur emosinya ketika berselisih dengan sopir sehingga tidak kebut-kebutan dan membahayakan orang lain.

Perilaku mengemudi yang berbahaya ini disebut dangerous driving behavior. Menurut Dula dan Geller (2003), dangerous driving behavior adalah perilaku pengendara dalam berkendaraan yang membahayakan atau berpotensi membahayakan pengendara lain, penumpang, dan juga penyeberang jalan. Menurut Dula dan Ballard (2003) ada tiga aspek dangerous driving behavior $(D D B)$ yaitu aggressive driving, negative emotive while driving, dan risky driving.

Ada beberapa faktor yang memengaruhi dangerous driving behavior. Menurut Tasca (2000) faktor yang mempengaruhi dangerous driving behavior yaitu usia dan jenis kelamin; anonimitas; faktor sosial; faktor personal; serta faktor lingkungan. Emosi merupakan salah satu faktor personal yang memengaruhi dangerous driving behavior (The Health and Safety Authority, An Garda Siochána or the Road Safety Authority, 2012).

Menurut Mesken (2006), efek dari emosi pada perilaku mengemudi secara nyata dapat diidentifikasi oleh pengukuran kecepatan selama mengemudi. Individu yang marah selama mengemudi cenderung mengemudi melampaui batas kecepatan. Menurut Arnau-Sabatés, SalaRoca, dan Jariot-Garcia (2012), sikap yang cenderung beresiko atau berbahaya mempunyai hubungan negatif dengan kemampuan emosional. Individu yang memiliki kemampu an emosional yang rendah cenderung untuk melakukan risky driving behavior. Selain itu, Trogolo, Melchior, dan Medrano (2014) juga melakukan penelitian yang hasilnya yaitu seseorang yang kesulitan dalam regulasi emosi diasosiasikan dengan risky driving. Berdasarkan ketiga penelitian dapat disimpulkan bahwa emosi berpengaruh terhadap perilaku mengemudi.

Menurut Trogolo, Melchoir dan Medrano (2014), seseorang yang memiliki regulasi emosi dapat mengendalikan dan mempertahankan emosinya, sehingga dapat lebih sabar dan toleran terhadap pengguna jalan yang lain. Sedangkan pengemudi yang tidak dapat mengen dalikan emosi negatif yang dirasakannya mempunyai kecenderungan untuk mengemudi secara berbahaya. Kemampuan tidak dapat mengendalikan emosi disebut juga kesulitan meregulasi emosi.

Menurut Ibraheim, Kalpakci, dan Sharp (2017), kesulitan meregulasi emosi secara umum diartikan sebagai seberapa sering dan seberapa intens pengalaman dari kombinasi emosi dengan ketidakmampuan untuk mengatasi masalah yang terjadi. Selain itu, Gratz dan Roemer (2004), juga menjelaskan bahwa kesulitan meregulasi emosi merupakan ketiadaaan atau kekurangan dari beberapa maupun semua kemampuan yang meliputi kesadaran dan pemahaman emosi, penerimaan emosi, kemampuan untuk mengendalikan perilaku yang diinginkan ketika mengalami emosi negatif, dan kemampuan untuk menggunakan strategi regulasi emosi yang tepat dan fleksibel untuk 
mengatur respon emosional sesuai tujuan yang diinginkan individu dan tuntutan masyarakat). Ada beberapa aspek kesulitan meregulasi emosi (Gratz \& Roemer, 2004) yaitu ketidakterimaan terhadap respon emosi (nonacceptance), kesulitan menjalankan perilaku sesuai tujuan yang diinginkan (goals), kesulitan mengontrol dorongan (impulse), kurangnya kesadaran emosi (awareness), keterbatasan dalam melakukan strategi pengaturan emosi (strategies), kurangnya kejelasan emosi (clarity).

Belum ada penelitian yang mengkaji fenomena sopir bus jurusan Magelang-Sukorejo dan jurusan Magelang-Wonosobo yang mengemudi kebut-kebutan dan membahayakan. Padahal dangerous driving behavior atau perilaku mengemudi yang berbahaya sangat membahayakan keselamatan dan keamanan penumpang. Selain itu, semakin tinggi angka kecelakaan yang diakibatkan oleh pengendara yang tidak mengemudi dengan baik. Oleh karena itu, peneliti ingin meneliti tentang pengaruh kesulitan meregulasi emosi terhadap dangerous driving behavior sopir bus antar-kota jurusan Magelang-Sukorejo dan Magelang-Wonosobo yang melalui jalur Temanggung. Berdasarkan uraian di atas peneliti ingin mengetahui bagaimana dangerous driving behavior sopir bus antar-kota jurusan Magelang-Wonosobo dan Magelang-Wonosobo yang melalui jalur Temanggung?

\section{METODE}

Penelitian dilakukan dengan pendekatan kuantitatif dan desain penelitian korelasi. Populasi penelitian sebanyak 128 sopir bus antar-kota jurusan Magelang Wonosobo dan Magelang-Sukorejo yang melalui jalur Temanggung. Teknik sampling yang digunakan adalah total sampling. Jadi sampelnya berjumlah 128 orang.

Penelitian dilakukan dengan pendekatan kuantitatif dan desain penelitian korelasi. Populasi penelitian sebanyak semua sopir bus sedang (jumlah kursi 16-35) antar-kota (MagelangWonosobo/Sukorejo) yang melalui jalur Temanggung; serta berjenis kelamin laki-laki. Berdasarkan data dari Perusahaan Otobus trayek Magelang-Wonosobo/Sukorejo yang melalui jalur Temanggung ada 128 bus. Jadi populasi penelitian yaitu sebanyak 128 orang. Teknik sampling yang digunakan adalah total sampling. Jadi sampelnya berjumlah 128 orang.

Variabel dalam penelitian ini adalah dangerous driving behavior dan kesulitan meregulasi emosi. Dangerous driving behavior adalah perilaku mengemudi yang berpotensi bahaya maupun membahayakan keselamatan dirinya dan orang lain baik yang lakukan secara sengaja maupun yang tidak disengaja. Dangerous driving behavior akan diukur berdasarkan aspek-aspek dari (Dula dan Ballard, 2003) yakni aggressive driving, negative emotion while driving, dan risky driving. Serta faktor-faktor yang memengaruhi (usia dan jenis kelamin, anonimitas, faktor sosial, dan faktor personal). Sedangkan kesulitan meregulasi emosi merupakan ketidakmampuan individu untuk mengendalikan emosi baik secara sadar maupun tidak sadar sesuai tujuan yang diinginkan individu 
dan tuntutan masyarakat. Pengukuran kesulitan meregulasi emosi melalui aspek-aspek dari Gratz dan Roemer (2004) yakni ketidakterimaan terhadap respon emosi (nonacceptance), kesukaran menjalankan perilaku sesuai tujuan yang diinginkan (goals), kesukaran mengontrol dorongan (impulse), kurangnya kesadaran emosi (awareness), keterbatasan dalam melakukan strategi pengaturan emosi (strategies), kurangnya kejelasan emosi (clarity).

Alat pengumpul data yang digunakan adalah Skala Dangerous Driving Behavior (DDDI) dan Skala Kesulitan Meregulasi Emosi (DERS). Skala Dangerous Driving Behavior terdiri dari 37 item yang memiliki koefisien daya beda aitem (r) 0.365- 0.782 dan reliabilitasnya sebesar 0.959. Sedangkan Skala Kesulitan Meregulasi Emosi terdiri dari 44 item yang memiliki koefisien daya beda aitem (r) 0.321- 0.768 dengan nilai reliabilitas sebesar 0.963 . Analisis data yang digunakan adalah analisis regresi sederhana dengan bantuan software pengolah data.

\section{HASIL DAN PEMBAHASAN}

Penelitian dilakukan di jalur Temanggung yang mencakup wilayah Magelang, Temanggung, Wonosobo dan Sukorejo (Kendal). Pengumpulan data dilaksanakan pada 18 Mei 2017 sampai dengan 01 Juni 2017. Peneliti menggunakan tryout terpakai dengan jumlah subjek penelitian sebanyak 128 orang untuk melakukan uji kuantitatif. Alasan menggunakan tryout terpakai disebabkan subjek yang tidak memiliki banyak waktu untuk mengisi instrumen penelitian. Selain itu, sulitnya peneliti menemui semua subjek yang tidak pasti tempat dan jam kerjanya menjadi pertimbangan peneliti menggunakan try out terpakai. Instrumen penelitian berbentuk booklet yang terdiri dari identitas, skala dangerous driving dan skala kesulitan meregulasi emosi.

Gambaran rentang usia subjek paling banyak berada di rentang usia 41-50 tahun yaitu sebesar 35,94\%. Gambaran dangerous driving behavior sebanyak $3.125 \%$ berada pada kategori sangat tinggi, $10.94 \%$ berada pada kategori tinggi, $15.625 \%$ berada pada kategori sedang, $27.34 \%$ berada pada kategori rendah dan $42.97 \%$ berada pada kategori sangat rendah. Gambaran kesulitan meregulasi emosi sebanyak $6.25 \%$ berada pada kategori sangat tinggi, $4.69 \%$ berada pada kategori tinggi, $15.63 \%$ berada pada kategori sedang, $28.91 \%$ berada pada kategori rendah dan $44.53 \%$ berada pada kategori sangat rendah.

Hasil uji normalitas menunjukkan bahwa signifikansi Kolmogorov Smirnov kedua skala yaitu skala Dangerous Driving Behavior dan skala kesulitan meregulasi emosi memiliki nilai yang lebih besar daripada taraf signifikansi, hal ini menandakan bahwa kedua data berdistribusi normal. Sehingga data ini dapat diinterpretasikan dengan populasi yang sesuai kriteria karena termasuk data parametrik. Selanjutnya untuk uji linieritas, skala dangerous driving behavior dan skala kesulitan meregulasi emosi memiliki nilai p sebesar 0.000. Nilai signifikansi kedua data berada di bawah 0.05 , sehingga hubungan kedua data yaitu dangerous driving behavior dan kesulitan meregulasi emosi adalah linier. 
Uji hipotesis yang dilakukan dengan analisis regresi sederhana menghasilkan uji korelasi antara kesulitan meregulasi emosi dan dangerous driving behavior diperoleh nilai koefisien (r) sebesar 0.881 dengan $\mathrm{p}$ sebesar 0.000 . Nilai $\mathrm{p}<0.01$ membuktikan bahwa ada hubungan positif yang signifikan antara kesulitan meregulasi emosi dan dangerous driving behavior. Dimana ketika nilai kesulitan meregulasi emosi tinggi maka nilai dangerous driving behavior juga tinggi. Selanjutnya diketahui F hitung sebesar 438.989 dengan taraf signifikansi 0.000 dimana $\mathrm{p}<0.05$, maka hipotesis diterima. Hal ini menunjukkan ada pengaruh kesulitan meregulasi emosi terhadap dangerous driving behavior sopir bus antar-kota jurusan Magelang-Wonosobo/Sukorejo yang melalui jalur Temanggung. Selain itu, diketahui bahwa nilai regresi antara kesulitan meregulasi emosi dan dangerous driving behavior (R Square) sebesar 0,777. Hasil ini menunjukkan bahwa 77,7 \% dangerous driving behavior sopir bus antar-kota jurusan Magelang-Wonosobo/Sukorejo yang melalui jalur Temanggung dipengaruhi oleh kesulitan meregulasi emosi. Sisanya, 23,3\% dipengaruhi oleh faktor-faktor lain yang tidak terungkap dalam penelitian ini. Menurut Tasca (2000), ada beberapa faktor yang memengaruhi dangerous driving behavior selain faktor emosi yaitu usia dan jenis kelamin, anonimitas, faktor sosial dan faktor lingkungan. Warner (2006) juga menyebutkan bahwa seseorang yang mempunyai sikap melanggar batas kecepatan, tidak dapat mengontrol perilaku, dan tidak menerima norma yang ada dapat digunakan untuk memprediksi pengemudi yang sering mengebut. Selanjutnya, Mashuri dan Zaduqisti (2009) juga menjelaskan bahwa fenomena dangerous driving bisa dijelaskan oleh faktor personal maupun faktor motivasional-situasional. Berdasarkan pendapat-pendapat tersebut dapat disimpulkan faktor-fakt or yang memengaruhi dangerous driving behavior selain kesulitan meregulasi emosi adalah usia, jenis kelamin, etnis, pengalaman mengemudi, faktor personal selain emosi, faktor sosial, dan faktor lingkungan.

Hasil diskriptif penelitian ini menunjukkan bahwa kesulitan meregulasi emosi sopir bus antar-kota jurusan Magelang-Sukorejo dan Magelang-Wonosobo yang melalui jalur Temanggung berada dalam kategori rendah. Kesulitan meregulasi emosi merupakan kebalikan dari regulasi emosi. Jadi regulasi emosi sopir bus antar-kota jurusan Magelang-Sukorejo dan MagelangWonosobo yang melalui jalur Temanggung berada dalam kategori tinggi. Aspek kesulitan menjalankan perilaku sesuai tujuan yang diinginkan (goals) ketika mengalami emosi negatif merupakan aspek yang memiliki konstribusi paling besar dalam menentukan tinggi rendahnya kesulitan meregulasi emosi. Sedangkan aspek kurangnya kesadaran emosi (awareness) merupakan aspek yang memiliki konstribusi paling kecil dalam menentukan tinggi rendahnya kesulitan meregulasi emosi.

Dangerous driving behavior sopir bus antar-kota jurusan Magelang-Sukorejo dan Magelan gWonosobo yang melalui jalur Temanggung berada dalam kategori rendah. Aspek negative emotion while driving merupakan aspek yang memiliki konstribusi paling besar dalam menentukan tinggi 
rendahnya dangerous driving behavior. Sedangkan aspek aggressive driving merupakan aspek yang memiliki konstribusi paling kecil dalam menentukan tinggi dangerous driving behavior.

Dampak regulasi emosi yang tinggi berpengaruh terhadap rendahnya dangerous driving behavior. Berdasarkan hasil wawancara dengan YS (50 tahun) pada tanggal 30 Mei 2016 didapatkan informasi bahwa kebut-kebutan antara dua sopir bus terjadi karena adanya sopir bus yang tidak sportif dan melanggar trayek bus lain. Sopir bus yang lain apabila tidak memiliki regulasi emosi yang baik akan mudah terpengaruh dan marah yang akhirnya terjadi kebut-kebutan. Sebaliknya sopir yang memiliki regulasi emosi tinggi akan mengendalikan amarahnya sehingga kebut-kebutan tidak terjadi. Hal ini sesuai dengan temuan Trogolo, Melchior, dan Medran o (2014) yaitu bahwa kesulitan meregulasi emosi berhubungan dengan kecemasan, marah, diasosiatif dan mengemudi yang beresiko (risky driving). Sebaliknya, individu tidak kesulitan dalam regulasi emosi diasosiasikan dengan careful driving.

Menurut Mesken (2006), efek dari emosi pada perilaku mengemudi secara nyata dapat diidentifikasi oleh pengukuran kecepatan selama mengemudi. Emosi yang dirasakan oleh pengemudi berpengaruh terhadap perilaku mengemudinya terutama emosi marah. Pengemudi yang menunjukkan kemarahan mengendarai kendaraannya melebihi batas kecepatan lebih daripada pengemudi yang tidak menunjukkan kemarahan. Sopir bus yang marah dengan sopir bus lain yang menyerobot wilayahnya menunjukkan ekspresi marahnya ini dengan melakukan kebut-kebutan (mengemudi melebihi batas kecepatan dan berbahaya). Hal ini menunjukkan bahwa emosi sangat berpengaruh terhadap perilaku mengemudi yang berbahaya.

Regulasi emosi sangat dibutuhkan oleh sopir. Arnau-Sabatés, Sala-Roca, dan Jariot-Garcia (2012) menemukan bahwa sikap yang cenderung beresiko atau berbahaya mempunyai hubungan negatif dengan kemampuan emosional. Hasil penelitiannya menunjukkan bahwa kemampuan emosional merupakan salah satu upaya pencegahan yang penting untuk mengurangi risky driving behaviour. Jadi, sopir bus yang memiliki kemampuan emosional yang rendah cenderung untuk melakukan risky driving behavior. Kesulitan meregulasi emosi merupakan salah satu kemampuan mengendalikan emosi.

Peneliti menduga rendahnya dangerous driving behavior dan tingginya regulasi emosi karena faktor usia. Menurut Sadewo (2015), nilai rerata tertinggi faktor-faktor yang memengaruhi dangerous driving behavior yaitu pada kelompok laki-laki, usia dewasa muda, etnis Sumatera dan pengalaman mengemudi lebih dari lima tahun. Jadi, usia yang memiliki nilai dangerous driving behavior yang tinggi adalah usia dewasa muda. Sedangkan pengelompokan subjek berdasarkan usia menunjukkan bahwa subjek yang berusia dewasa muda (20-30 tahun) hanya sebesar 16, $41 \%$. Sedangkan sisanya $83,59 \%$ berusia di atas 31 tahun.

Selain itu, peneliti menemukan adanya perbedaan dangerous driving behavior yang dimiliki sopir bus tipe $3 / 4$ (roda berjumlah 6) dan bus tipe engkel (roda berjumlah 4). Berdasarkan tabel perbandingan bus $3 / 4$ dan bus engkel diketahui bahwa sebagian sopir yang masuk kategori sangat 
tinggi dan kategori tinggi adalah sopir bus $3 / 4$. Sebanyak $8,16 \%$ dari 49 orang berada pada kategori sangat tinggi. Serta lebih dari seperempat sopir bus $3 / 4$ yaitu sebanyak $28,57 \%$ berada pada kategori tinggi. Sedangkan separuh lebih $(59,49 \%)$ dari 79 orang sopir bus engkel berada pada kategori sangat rendah. Selain itu, diketahui perbedaan jam kerja dan setoran antara sopir bus $3 / 4$ dan sopir bus engkel. Sebagian besar sopir bus 3/4 yaitu sebanyak $81,63 \%$ dari 49 orang bekerja selama lebih dari 12 jam. Sedangkan 88,61\% dari 79 sopir bus engkel bekerja selama 8-12 jam sehari. Sebagian besar setoran sopir bus 3/4 lebih dari Rp200.000,00 perhari. Sebanyak 59,18\% memberikan setoran Rp 200.000,00-Rp 300.000,00 perhari dan sebanyak 28,57\% memberikan setoran lebih dari $\mathrm{Rp}$ $300.000,00$ perhari. Sedangkan sebanyak 44,3\% sopir bus engkel memberikan setoran kurang dari $\mathrm{Rp}$ 100.000,00 perhari dan sebanyak 55,7\% sopir bus engkel memberikan setoran antara $\mathrm{Rp}$ 100.000,00- Rp 200.000,00 perhari. Berdasarkan penjabaran tersebut diketahui adanya perbedaan antara bus engkel dan bus $3 / 4$. Jadi ada perbedaan perilaku mengemudi antara sopir bus $3 / 4$ dan sopir bus engkel.

Berdasarkan uraian di atas diketahui bahwa meregulasi emosi berpengaruh terhadap dangerous driving behavior. Namun, ada faktor lain yang juga berpengaruh yaitu usia, pengalaman mengemudi, tuntutan kerja dan beban kerja.

\section{KESIMPULAN}

Dangerous driving behavior sopir terjadi ketika kondisi sopir jengkel dan marah. Aspek kesulitan menjalankan perilaku sesuai tujuan yang diinginkan (difficulties engaging in goaldirected behavior) adalah aspek kesulitan meregulasi emosi yang paling berdampak bagi dangerous driving behavior sopir. Adanya rasa jengkel dan marah ketika sopir tidak dapat memenuhi target kerja membuat sopir melakukan tindakan kebut-kebutan dan melanggar peraturan lalu lintas. Perilaku mengemudi yang berbahaya (dangerous driving behavior) seperti itu dapat menyebabkan terjadinya kecelakaan lalu lintas yang membahayakan dirinya maupun orang lain.

Pemerintah dapat mengurangi perilaku mengemudi yang berbahaya dengan membuat kebijakan yang terkait dengan persyaratan untuk mendapatkan Surat Izin Mengemudi (SIM). Kemampuan yang diujikan sebaiknya tidak hanya keahlian mengemudi dan pengetahuan tentang mengemudi. Namun, ditambah dengan uji kemampuan emosional calon pengemudi. Selain itu, pemerintah juga diharapkan memberikan sanksi yang tegas kepada sopir bus yang melanggar peraturan lalu lintas dan jam trayek sopir bus lain. Hal ini dilakukan untuk menghindari terjadin ya kebut-kebutan antar sopir bus.

Perusahaan Otobus dapat mengurangi perilaku mengemudi yang berbahaya dengan mengadakan rekrutmen sopir yang memenuhi syarat mengemudi secara aman. Syarat tersebut harus terpenuhi pada semua kemampuan baik kemampuan fisik dan kemampuan psikologis terutama kemampuan emosional. Selain itu, Perusahaan Otobus juga dapat mengadakan pelatih an 
regulasi emosi bagi sopir bus untuk meningkatkan kemampuan regulasi emosi yang dimiliki sopir bus.

Diharapkan bagi sopir untuk mempertahankan serta meningkatkan kemampuan regulasi emosi yang dimiliki. Dengan kemampuan regulasi emosi yang baik maka sopir tidak mudah untuk berperilaku mengemudi secara berbahaya.

Berdasarkan temuan penelitian, diharapkan peneliti selanjutnya yang ingin membuat penelitian serupa dapat mengembangkan topik penelitian perbandingan dangerous driving behavior sopir bus $3 / 4$ dan sopir bus engkel. Selain itu, peneliti selanjutnya juga dapat mengembangkan topik tentang pelatihan regulasi emosi untuk sopir.

\section{DAFTAR PUSTAKA}

Arnau-Sabatés, L., Sala-Roca, J., \& i Jariot-Garcia, M. (2012). Emotional abilities as predictors of risky driving behavior among a cohort of middleaged drivers. Accident Analysis \& Prevention, 45, 818-825.

Dula, C.S., \& Ballard, M.E. (2003). Development and evaluation of a measure of dangerous, aggressive, negative emotional, and risky driving. Journal of Applied Social Psychology, 263-282.

Dula, C.S., \& Geller, E.S. (2003). Risky, aggressive or emotional driving: Addressing the need for consistent communication in research. Journal of Safety Research, 599-606.

Gratz, K.L., \& Roemer, L. (2004). Multidimensional assesment of emotion regulation and dysregulation: develpoment, factor structure, and initial validation of the difficulties of emotion regulation scale. Journal of Psychopathology and Behavioral Assesment, 41-54.

Hazliansyah, \& Supriyanto, A. (2013, Januari 21). Ugal-ugalan, bus tabrak tiga motor. Diunduh Mei 16, 2016, from republika.co.id:http://nasional. republika.co.id/berita/nasional/daerah/13/01/21/mgys5k-ugalugalan-bus-tabrak-tiga-motor.

Ibraheim, M., Kalpakci, A., \& Sharp, C. (2017). The specificity of emotion dysregulation in adolescents with boderline personality disorder: Comparison with psychiatric and healthy controls. Boderline Personality Disorder and Emotion Dysregulation,1-9.

Marsaid., Hidayat, M., \& Ahsan. (2013). Faktor yang berhubungan dengan kejadian kecelakaan lalu lintas pada pengendara sepeda motor di wilayah polres kabupaten Malang. Jurnal Ilmu Keperawatan, 98-112.

Mashuri, A., \& Zaduqisti, E. (2009). Dangerous driving, prediktor dan mediatornya. Psycho Idea, $7(1), 22-34$.

Mesken, J. (2006). Determinants and consequences of drivers' emotions. Leidschendam: Stichting Wetenschappelijk Onderzoek Verkeersveiligheid SWOV.

Rostanti, Q., \& Hafil, M. (2017, 02 Mei). Jumlah kecelakaan di indonesia empat tahun terakhir. Diunduh Mei 08, 2017, dari http://nasional.republika.co. id/berita/nasional/umum/17/05/02/opaywe326-jumlah-kecelakaan-di-indonesia-empat-tahunterakhir.

Sadewo, Y. (2015, November 18). Dangerous driving behavior pada pengendara sepeda motor (studi deskriptif). Diunduh Mei 24, 2016, dari library.gunadarma.ac.id: library.gunadarma.ac.id/repository/view/3810975/dangerous-driving-behavior-padapengendara-sepeda-motor-studi-deskriptif.html/ 
Tasca, L. (2000). A review of the literature on aggressive driving research. Diunduh Juni 01, 2016 dari Aggressive Driving Issues Conference: http://www.aggressive.drivers.com/issues/roadrage/2driv.html

Tanjung, C.A. (2016, 05 September). Sopir Bus Ugal-ugalan Tabrak Truk, 4 Orang Tewas di Riau. Diunduh Mei 08, 2017, dari https://news.detik.com/ berita/3290776/sopir-bus-ugal-ugalantabrak-truk-fuso-4-orang-tewas-di-riau

Trógolo, M.A., Melchior, F., \& Medrano, L.A. (2014). The role of difficulties in emotion regulation on driving behavior. Journal of Behavior, Health \& Social Issues, 107-117. 